\title{
Development and Validation of a Perfect KASP Marker for Fusarium Head Blight Resistance Gene Fhb1 in Wheat
}

\author{
Lovepreet Singh ${ }^{1}$, James A Anderson ${ }^{2}$, Jianli Chen ${ }^{3}$, Bikram S Gill, Vijay K Tiwari ${ }^{1}$, and Nidhi Rawat (D) ${ }^{1 *}$ \\ ${ }^{I}$ Department of Plant Science and Landscape Architecture, University of Maryland, College Park, MD 20742, USA \\ ${ }^{2}$ Department of Agronomy and Plant Genetics, University of Minnesota, St. Paul, MN 55108, USA \\ ${ }^{3}$ Department of Plant, Soil, and Entomological Sciences, University of Idaho, Aberdeen, ID 83210, USA \\ ${ }^{4}$ Wheat Genetics Resource Center, Department of Plant Pathology, Kansas State University, Manhattan, Kansas, KS \\ 66506, USA
}

(Received on January 27, 2019; Revised on March 16, 2019; Accepted on March 31, 2019)

Fusarium head blight (FHB) is a devastating wheat disease with a significant economic impact. Fhb1 is the most important large effect and stable QTL for FHB resistance. A pore-forming toxin-like (PFT) gene was recently identified as an underlying gene for $F h b 1$ resistance. In this study, we developed and validated a PFTbased Kompetitive allele specific PCR (KASP) marker for Fhb1. The KASP marker, PFT_KASP, was used to screen 298 diverse wheat breeding lines and cultivars. The KASP clustering results were compared with gelbased gene specific markers and the widely used linked STS marker, UMN10. Eight disagreements were found between PFT_KASP and UMN10 assays among the tested lines. Based on the genotyping and sequencing of genes in the $F h b 1$ region, these genotypes were found to be common with a previously characterized susceptible haplotype. Therefore, our results indicate that PFT KASP is a perfect diagnostic marker for Fhb1 and would be a valuable tool for introgression and pyramiding of FHB resistance in wheat cultivars.

\footnotetext{
*Corresponding author.

Phone) +1-301-405-9744, FAX) +1-301-314-9308

E-mail)nidhirwt@umd.edu

ORCID

Nidhi Rawat

https://orcid.org/0000-0003-4820-0020
}

\begin{abstract}
(c) This is an Open Access article distributed under the terms of the Creative Commons Attribution Non-Commercial License (http:// creativecommons.org/licenses/by-nc/4.0) which permits unrestricted noncommercial use, distribution, and reproduction in any medium, provided the original work is properly cited.
\end{abstract}

Articles can be freely viewed online at www.ppjonline.org.
Keywords: Fhb1, Fusarium head blight, KASP assay, poreforming toxin-like (PFT), Wheat

Handling Editor: Park, Chang-Jin

Fusarium head blight (FHB), also known as head scab, is a devastating wheat disease with a significant economic impact. FHB incidences have been reported at epidemic levels across the USA, several parts of Canada, Europe, China and Korea since the 1990s (Goswami and Kistler, 2004; McMullen et al., 2012; Shin et al., 2018; Windels, 2000). The total direct and indirect losses due to FHB in wheat and barley were estimated to be $\$ 7.67$ billion from 1993 to 2001 across nine states in the northern Great Plains and the Central USA (Nganje et al., 2004). In addition to lower yields, FHB infected grains accumulate trichothecenes and estrogenic mycotoxins that make grain unfit for animal and human consumption (Goswami and Kistler, 2004). Deoxynivalenol (DON) is the major toxin associated with FHB (McMullen et al., 1997) and its consumption causes vomiting, feed refusal, and diarrhea in animals (Bennett and Klich, 2003). In North America, Fusarium graminearum Schwabe is reported as a major causal agent of FHB. Besides wheat, the pathogen also infects other important cereal crops including barley, corn, oat, and rye (Goswami and Kistler, 2004).

Among various management practices, growing disease resistant cultivars is the most effective and economical disease management strategy against FHB (McMullen et al., 1997). Although quantitative trait loci (QTLs) associated with FHB have been found on all the wheat chromosomes, Fhbl is the most important large effect and stable QTL for FHB resistance derived from Chinese cultivar 'Sumai 
3' (Buerstmayr et al., 2009). Sumai 3 was developed by crossing two moderately susceptible parents 'Funo' and 'Taiwanxiaomai' and it has been widely used in wheat breeding programs as a source for FHB resistance (Bai and Shaner, 1994). Fhb1 confers resistance against spread of the pathogen on the spike after initial infection, also known as type II resistance (Schroeder and Christensen, 1963). Fhbl is located on the short arm of chromosome 3B of Sumai 3 (Anderson et al., 2001; Xiao et al., 2011). A poreforming toxin-like (PFT) gene was identified as an underlying gene for $F h b 1$ resistance. $P F T$ is a 3,472 bp gene with two exons which is predicted to encode two agglutinin domains and one pore forming ETX/MTX2 domain (Rawat et al., 2016). Five different haplotypes for the $F h b 1$ region, including one resistant (R) and four susceptible (S1, S2, S3, and S4) haplotypes were reported by Rawat et al. (2016) in a panel of 40 landraces and cultivars with a well-characterized FHB phenotype. PFT was present only in R and S3 haplotypes, and both haplotypes differ by two SNPs (Rawat et al., 2016).

DNA marker-assisted selection (MAS) is highly desirable for selecting FHB resistance due to its quantitative nature, high Genotype x Environment interaction (GxE), and requirement of adult plant screening (Buerstmayr et al., 2009). Traditionally, MAS for $F h b 1$ has been reported using linked simple sequence repeat (SSR) markers (Anderson et al., 2007; Miedaner et al., 2006; Wilde et al., 2007; Xie et al., 2007; Zhou et al., 2003). However, linked SSR mark- ers have limitations in their utility. First, recombination between the marker and underlying gene might occur after multiple selection cycles. Second, lack of polymorphism might become an issue with introgression into diverse genetic backgrounds. Third, haplotype variation of markers not associated with the causal gene can result in false positives or false negatives. Finally, SSR markers are gel-based markers and require a fragment analysis step in addition to polymerase chain reaction (PCR). Single Nucleotide Polymorphism (SNP) markers are the markers of choice among contemporary breeding programs due to high throughput, gel-free detection, and low cost (Gupta et al., 2001; Singh and Singh, 2015). Kompetitive allele specific PCR (KASP) is a high-throughput and breeder friendly fluorescencebased genotyping platform for SNP markers (Semagn et al., 2014). In wheat, KASP markers have been developed and validated for leaf rust resistance (Neelam et al., 2013), stem rust resistance (Babiker et al., 2015), wheat streak mosaic virus resistance (Tan et al., 2017) and pre-harvest sprouting resistance (Cabral et al., 2014). Bernardo et al. (2012) developed SNP markers flanking the Fhbl locus using a Ning 7840/Clark population. KASP markers linked with Fhb1 have been developed (Rasheed et al., 2016; Steiner et al., 2017; Su et al., 2018), but still there is a need to develop a gene-specific perfect KASP marker for Fhb1. The objectives of this study were to develop and validate a gene specific perfect KASP marker for Fhb1. PFT_KASP will enhance breeding efficiency for FHB resistance.
Jingzhou1
Nanda2419
Emai6
WZHHS
Shanasui
Wannin2
Sumai-3
Huoshawmai
ShuiLizhan
701Chokwang

Jingzhou 1

Nanda2419

Emai 6

WZHHS

Shanasui

Wannin2

Sumai-3

Huoshawmai

ShuiLizhan

701Chokwang
ACCAGCAGGGATACAGCCTGACTTTCGTGATTATCTCTCCCATCTTATGTTTGCAATCGT 298 ACCAGCAGGGATACAGCCTGACTTTCGTGATTATCTCTCCCATCTTATGTTTGCAATCGT 292 ACCAGCAGGGATACAGCCTGACTTTCGTGATTATCTCTCCCATCTTATGTTTGCAATCGT 298 ACCAGCAGGGATACAGCCTGACTTTCGTGATTATCTCTCCCATCTTATGTTTGCAATCGT 295 ACCAGCAGGGATACAGCCTGACTTTCGTGATTATCTCTCCCATCTTATGTTTGCAATCGT 295 ACCAGCAGGGATACAGCCTGACTTTCGTGATTATCTCTCCCATCTTATGTTTGCAATCGT 293 ACCAGCAGGGATACAGCCTGACTTTCGTGATTATCTCTCCCATCTTATGTTTGCAATCGT 291 ACCAGCAGGGATACAGCCTGACTTTCGTGATTATCTCTCCCATCTTATGTTTGCAATCGT 293 ACCAGCAGGGATACAGCCTGACTTTCGTGATTATCTCTCCCATCTTATGTTTGCAATCGT 293 ACCAGCAGGGATACAGCCTGACTTTCGTGATTATCTCTCCCATCTTATGTTTGCAATCGT 293

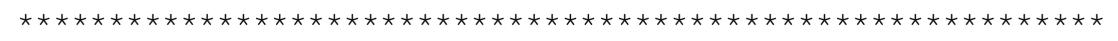

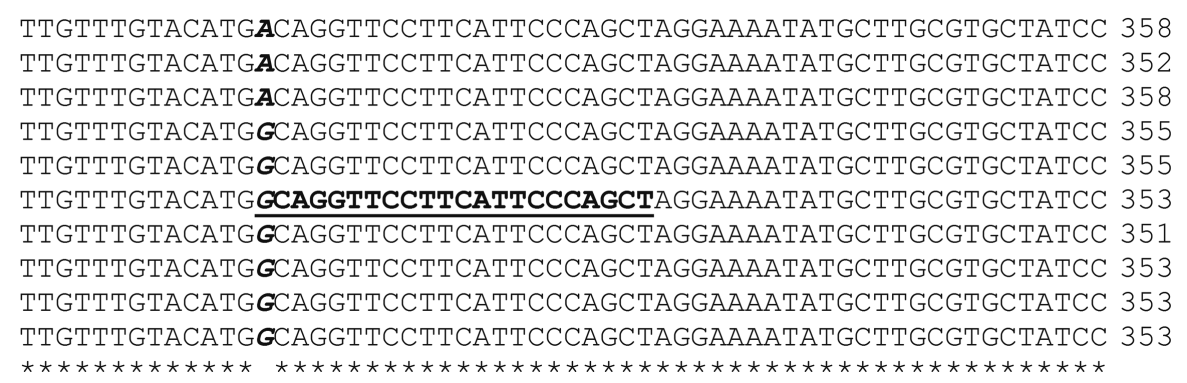

Fig. 1. Multiple sequence alignment of wheat accessions representing R and S3 haplotypes for PFT. WZHHS, Shanasui, Wannin2, Sumai-3, Huoshawmai, Shuilizhan, and 701 Chokwang contain R haplotype, whereas, Jingzhou1, Nanda2419, and Emai6 possess S3 haplotype. Asterisks designate the consensus sequence among all the genotypes. The position of allele specific and common primer is highlighted as bold underlined. The SNP targeted for developing PFT_KASP is highlighted as bold italics. 
Table 1. List of primer sequences used in this study

\begin{tabular}{lll}
\hline Marker & Primer & Sequence $\left(5^{\prime}{ }^{\prime}{ }^{\prime}\right.$ ') \\
\hline PFT_KASP & Reverse_G & AGCTGGGAATGAAGGAACCTGC \\
& Reverse_A & AGCTGGGAATGAAGGAACCTGT \\
& Common Forward & GTGATTATCTCTCCCATCTTATGTTTGCAA \\
PFT_TILLING & Forward & TGGCACACGCTACATTGCT \\
(Rawat et al., 2016) & Reverse & CAACTTCGCCGTCAACTACA \\
PFT_GSP & Forward & ATAATCTCCTTGATGCTTTTACT \\
& Reverse & ACTATCAAGGCCCTCAATACCA \\
SGNH_GSP & Forward & CAATTCCAGCAGTTCATCAAC \\
& Reverse & CATACCCGCAACACACAT \\
His & Forward & AAGGAGAAGAAGCTCAAGTCG \\
& Reverse & CTGGGTTCAGCAGAGTTCGCAC \\
TS & Forward & GTACACTCGGGACCGTATGGTC \\
& Reverse & GGAGATGTCGTTGAGGAAGCGG \\
UMN10 & Forward & CGTGGTTCCACGTCTTCTTA \\
(Liu et al., 2008) & Reverse & TGAAGTTCATGCCACGCATA \\
\hline
\end{tabular}

\section{Materials and Methods}

Plant materials. A panel of 40 landraces was used to test diagnostic ability of the KASP marker (Supplementary Table 1). For marker validation, 75 breeding lines from University of Idaho's spring wheat breeding program were used (Table 2). Additionally, 223 diverse wheat entries including cultivars and breeding lines maintained at the University of Minnesota and Pacific Northwest wheat breeding programs were used for genotyping (Supplementary Table 2).

Primer design. The PFT sequences were amplified using PFT_TILLING primer used for performing Targeting Induced Local Lesions in Genomes (TILLING) in Rawat et al. (2016) from the accessions representing R and S3 haplotypes. For developing a $P F T$ specific KASP marker, we targeted the G/A polymorphism between R and S3 haplotype at the 2,181 nucleotide position where the $G$ nucleotide was specific to R haplotype (Fig. 1). The KASP marker, PFT_KASP, was designed at the target SNP from LGC genomics (LGC Ltd, Teddington, UK). The sequences of two allele specific reverse primers and one common forward primer for PFT_KASP are given in Table 1. For validating the PFT_KASP marker, the 298 wheat breeding lines and cultivars were also screened for the STS marker UMN10 (Liu et al., 2008), gel-based gene specific markers for PFT (PFT_GSP), and a neighboring gene $S G N H$ (SGNH_GSP) belonging to GDSL lipase superfamily in the Fhb1 region (Table 1). PFT_GSP was designed to tar- get the G/A polymorphism between R and S3 haplotypes. SGNH_GSP was also designed to specifically amplify $\mathrm{R}$ haplotype. Table 1 enlists all the primer sequences used in this study.

Genotyping assays. The KASP assay was performed in 10 $\mu 1$ reaction volume consisting of $5 \mu 1$ KASP master mix, $0.14 \mu \mathrm{l} \mathrm{KASP}$ primer assay mix and $5 \mu \mathrm{l}$ of $10 \mathrm{ng} / \mu \mathrm{l}$ DNA template. The amplification and Fluorescent end-point reading were performed on a BIO-RAD CFX 96 (BioRad Laboratories Inc., Hercules, CA, USA). The following cycling conditions were used: $94^{\circ} \mathrm{C}$ for $15 \mathrm{~min}$, ten touchdown cycles of $94^{\circ} \mathrm{C}$ for $20 \mathrm{~s}$ and $61-55^{\circ} \mathrm{C}$ (dropping $0.6^{\circ} \mathrm{C}$ per cycle) for $1 \mathrm{~min}$; followed by 26 cycles of $94^{\circ} \mathrm{C}$ for $20 \mathrm{~s}$ and $55^{\circ} \mathrm{C}$ for $1 \mathrm{~min}$. The Fluorescent end-point reading was done at $30^{\circ} \mathrm{C}$ for $1 \mathrm{~min}$. The allele discrimination mode of BIO-RAD CFX manager 3.1 software was used for genotype calling. It is important to note that the distinction of $\mathrm{S} 3$ haplotype from R haplotype in this KASP assay is based on just one SNP, we recommend the strict use of the above thermocycler profile. The PCR for PFT_GSP and SGNH GSP was performed in $25 \mu \mathrm{l}$ reaction volume including $\overline{5}$ $\mu \mathrm{l}$ of $5 \times \mathrm{MyTaq}^{\mathrm{TM}}$ Buffer (Bioline), $2 \mu \mathrm{l}$ of each forward and reverse primer $(4 \mu \mathrm{M} / \mu \mathrm{l}), 0.1 \mu \mathrm{l}$ of $5 \mathrm{U} / \mu \mathrm{l} \mathrm{MyTaq}{ }^{\mathrm{TM}}$ DNA Polymerase (Bioline) and $75 \mathrm{ng}$ of DNA template. The PCR amplifications were run on $\mathrm{T} 100^{\mathrm{TM}}$ thermal cycler (Bio-Rad Laboratories Inc., Hercules, CA, USA) by using cycling profile as follows: $95^{\circ} \mathrm{C}$ for $5 \mathrm{~min}$, five touchdown cycles of $95^{\circ} \mathrm{C}$ for $45 \mathrm{~s}, 65-60^{\circ} \mathrm{C}$ (dropping $1^{\circ} \mathrm{C}$ per cycle) for $45 \mathrm{~s}$ and $72^{\circ} \mathrm{C}$ for $1 \mathrm{~min}$; followed by 27 cycles of $95^{\circ} \mathrm{C}$ for $45 \mathrm{~s}, 60^{\circ} \mathrm{C}$ for $45 \mathrm{~s}$ and $72^{\circ} \mathrm{C}$ for $1 \mathrm{~min}$; with 


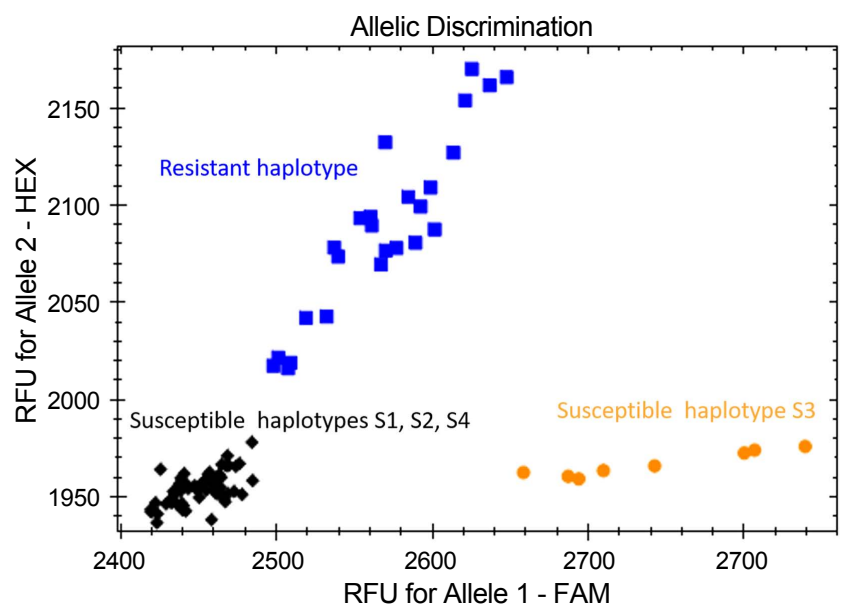

Fig. 2. Genotyping results of PFT_KASP marker on a panel of different genotypes and controls. Genotypes clustered as blue squares in the upper left corner are homozygous resistant (R) haplotype. Genotypes clustered in the lower right corner as orange circles are homozygous susceptible (S3) haplotype. Genotypes which do not possess either allele are clustered with NTCs (No template controls) as black diamonds in the lower left corner. final extension for $7 \mathrm{~min}$ at $72^{\circ} \mathrm{C}$. The PCR products were visualized with ethidium bromide after running on $1.8 \%$ agarose gels. The methods for UMN10 genotyping were as described previously (Liu et al., 2008).

\section{Results and Discussion}

The KASP assay developed for PFT targeted the SNP between R and S3 haplotype (Fig. 1), and all the other susceptible haplotypes lack PFT. PFT_KASP therefore behaves as a dominant marker. The PFT_KASP assay accurately clustered genotypes into three clusters of R haplotype, S3 haplotype and other susceptible haplotypes in the panel of 40 landraces and controls for all the haplotypes (Fig. 2). As the rate of recombination is very low in the Fhbl region (Rawat et al., 2016; Shweiger et al., 2016), other co-dominant markers known from the $F h b 1$ region such as widely used UMN10 (Liu et al., 2008) or recently reported HRCGSM (Su et al., 2018) may be used to discern heterozygosity or homozygosity in breeding programs.

Table 2. Genotyping results of PFT_KASP, UMN10, SGNH_GSP, and PFT_GSP markers on the set of University of Idaho wheat breeding lines used for validation of PFT_KASP marker

\begin{tabular}{llcccc}
\hline Breeding line ID & Pedigree & PFT_KASP & UMN10 & SGNH_GSP & PFT_GSP \\
\hline A12023S-1 & IDO850/W14//IDO852 & $\mathrm{S}$ & $\mathrm{S}$ & $\mathrm{S}$ & $\mathrm{S}$ \\
A12023S-4 & IDO850/W14//IDO852 & $\mathrm{S}$ & $\mathrm{S}$ & $\mathrm{S}$ & $\mathrm{S}$ \\
A12023S-5 & IDO850/W14//IDO852 & $\mathrm{S}$ & $\mathrm{S}$ & $\mathrm{S}$ & $\mathrm{S}$ \\
A12025S-1 & IDO850/W14//IDO854 & $\mathrm{S}$ & $\mathrm{S}$ & $\mathrm{S}$ & $\mathrm{S}$ \\
A12025S-2 & IDO850/W14//IDO854 & $\mathrm{R}$ & $\mathrm{R}$ & $\mathrm{R}$ & $\mathrm{R}$ \\
A12025S-4 & IDO850/W14//IDO854 & $\mathrm{S}$ & $\mathrm{S}$ & $\mathrm{S}$ & $\mathrm{S}$ \\
A12035S-1 & IDO851/W14//IDO851 & $\mathrm{S}$ & $\mathrm{S}$ & $\mathrm{S}$ & $\mathrm{S}$ \\
A12037S-3 & IDO851/W14//IDO854 & $\mathrm{S}$ & $\mathrm{S}$ & $\mathrm{S}$ & $\mathrm{S}$ \\
A12037S-5 & IDO851/W14//IDO854 & $\mathrm{S}$ & $\mathrm{S}$ & $\mathrm{S}$ & $\mathrm{S}$ \\
A12037S-7 & IDO851/W14//IDO854 & $\mathrm{S}$ & $\mathrm{S}$ & $\mathrm{S}$ & $\mathrm{S}$ \\
A12056S-10 & IDO852//IDO852/W14 & $\mathrm{S}$ & $\mathrm{S}$ & $\mathrm{S}$ & $\mathrm{S}$ \\
A12056S-11 & IDO852//IDO852/W14 & $\mathrm{S}$ & $\mathrm{S}$ & $\mathrm{S}$ & $\mathrm{S}$ \\
A12056S-12 & IDO852//IDO852/W14 & $\mathrm{S}$ & $\mathrm{S}$ & $\mathrm{S}$ & $\mathrm{S}$ \\
A12056S-13 & IDO852//IDO852/W14 & $\mathrm{R}$ & $\mathrm{R}$ & $\mathrm{R}$ & $\mathrm{R}$ \\
A12062S-6 & IDO854/W14//IDO851 & $\mathrm{R}$ & $\mathrm{H}$ & $\mathrm{R}$ & $\mathrm{R}$ \\
A12062S-8 & IDO854/W14//IDO851 & $\mathrm{R}$ & $\mathrm{H}$ & $\mathrm{R}$ & $\mathrm{R}$ \\
A12062S-9 & IDO854/W14//IDO851 & $\mathrm{S}$ & $\mathrm{S}$ & $\mathrm{S}$ & $\mathrm{S}$ \\
IDO1405S & 2016 F311 E border & $\mathrm{S}$ & $\mathrm{S}$ & $\mathrm{S}$ & $\mathrm{S}$ \\
A12063S-9 & IDO854/W14//IDO854 & $\mathrm{S}$ & $\mathrm{S}$ & $\mathrm{S}$ & $\mathrm{S}$ \\
A12063S-10 & IDO854/W14//IDO854 & $\mathrm{S}$ & $\mathrm{S}$ & $\mathrm{S}$ & $\mathrm{S}$ \\
A12063S-12 & IDO854/W14//IDO854 & $\mathrm{S}$ & $\mathrm{S}$ & $\mathrm{S}$ & $\mathrm{S}$ \\
A12064S-1 & IDO854/W14//IDO854 & $\mathrm{S}$ & $\mathrm{S}$ & $\mathrm{S}$ & $\mathrm{S}$ \\
A12064S-2 & IDO854/W14//IDO854 & $\mathrm{S}$ & $\mathrm{S}$ & $\mathrm{S}$ & $\mathrm{S}$ \\
A12064S-8 & IDO854/W14//IDO854 & $\mathrm{S}$ & $\mathrm{S}$ & $\mathrm{S}$ & $\mathrm{S}$ \\
A12064S-9 & IDO854/W14//IDO854 & $\mathrm{S}$ & $\mathrm{S}$ & $\mathrm{S}$ & $\mathrm{S}$ \\
A12064S-11 & IDO854/W14/IDO854 & $\mathrm{S}$ & $\mathrm{S}$ & $\mathrm{S}$ \\
A12077S-2 & IDO696//IDO696/W14 & & & \\
\hline
\end{tabular}


Table 2. Continued

\begin{tabular}{|c|c|c|c|c|c|}
\hline Breeding line ID & Pedigree & PFT_KASP & UMN10 & SGNH_GSP & PFT_GSP \\
\hline A12084S-3 & IDO687//IDO687/W14 & $\mathrm{R}$ & $\mathrm{H}$ & $\mathrm{R}$ & $\mathrm{R}$ \\
\hline A12084S-5 & IDO687//IDO687/W14 & $\mathrm{R}$ & $\mathrm{H}$ & $\mathrm{R}$ & $\mathrm{R}$ \\
\hline A12084S-6 & IDO687//IDO687/W14 & $\mathrm{R}$ & $\mathrm{H}$ & $\mathrm{R}$ & $\mathrm{R}$ \\
\hline A12084S-7 & IDO687//IDO687/W14 & $\mathrm{S}$ & $\mathrm{S}$ & $\mathrm{S}$ & $\mathrm{S}$ \\
\hline A12086S-3 & IDO687/W14//IDO687 & $\mathrm{R}$ & $\mathrm{R}$ & $\mathrm{R}$ & $\mathrm{R}$ \\
\hline A12086S-10 & IDO687/W14//IDO687 & $\mathrm{R}$ & $\mathrm{R}$ & $\mathrm{R}$ & $\mathrm{R}$ \\
\hline A12086S-12 & IDO687/W14//IDO687 & $\mathrm{R}$ & $\mathrm{R}$ & $\mathrm{R}$ & $\mathrm{R}$ \\
\hline A12086S-13 & IDO687/W14//IDO687 & $\mathrm{S}$ & $\mathrm{S}$ & $\mathrm{S}$ & $\mathrm{S}$ \\
\hline A12004S-1 & IDO694/N9016/3/JFSN*4/IDO584 (70-5)//Lassik & $\mathrm{S}$ & $\mathrm{S}$ & $\mathrm{S}$ & $\mathrm{S}$ \\
\hline A12004S-3 & IDO694/N9016/3/JFSN*4/IDO584 (70-5)//Lassik & $\mathrm{S}$ & $\mathrm{S}$ & $\mathrm{S}$ & $\mathrm{S}$ \\
\hline A12004S-10 & IDO694/N9016/3/JFSN*4/IDO584 (70-5)//Lassik & $\mathrm{S}$ & $\mathrm{S}$ & $\mathrm{S}$ & $\mathrm{S}$ \\
\hline A12004S-14 & IDO694/N9016/3/JFSN*4/IDO584 (70-5)//Lassik & $\mathrm{S}$ & $\mathrm{S}$ & $\mathrm{S}$ & $\mathrm{S}$ \\
\hline IDO1603S & 2016 Gp 100 & S3 & $\mathbf{R}$ & $\mathbf{S}$ & $\mathbf{S}$ \\
\hline UI Stone & 2016 Gp 100 & $\mathrm{~S}$ & $\mathrm{~S}$ & $\mathrm{~S}$ & $\mathrm{~S}$ \\
\hline A12004S-15 & IDO694/N9016/3/JFSN*4/IDO584 (70-5)//Lassik & $\mathrm{S}$ & $\mathrm{S}$ & $\mathrm{S}$ & $\mathrm{S}$ \\
\hline A12004S-16 & IDO694/N9016/3/JFSN*4/IDO584 (70-5)//Lassik & $\mathrm{S}$ & $\mathrm{S}$ & $\mathrm{S}$ & $\mathrm{S}$ \\
\hline A12004S-17 & IDO694/N9016/3/JFSN*4/IDO584 (70-5)//Lassik & $\mathrm{S}$ & $\mathrm{S}$ & $\mathrm{S}$ & $\mathrm{S}$ \\
\hline A12004S-18 & IDO694/N9016/3/JFSN*4/IDO584 (70-5)//Lassik & $\mathrm{S}$ & $\mathrm{S}$ & $\mathrm{S}$ & $\mathrm{S}$ \\
\hline A12004S-19 & IDO694/N9016/3/JFSN*4/IDO584 (70-5)//Lassik & S3 & $\mathbf{R}$ & $\mathbf{S}$ & $\mathbf{S}$ \\
\hline A12004S-20 & IDO694/N9016/3/JFSN*4/IDO584 (70-5)//Lassik & $\mathrm{S}$ & $\mathrm{S}$ & $\mathrm{S}$ & $\mathrm{S}$ \\
\hline A12004S-21 & IDO694/N9016/3/JFSN*4/IDO584 (70-5)//Lassik & $\mathrm{S}$ & $\mathrm{S}$ & $\mathrm{S}$ & $\mathrm{S}$ \\
\hline A12004S-24 & IDO694/N9016/3/JFSN*4/IDO584 (70-5)//Lassik & S3 & $\mathbf{R}$ & $\mathbf{S}$ & $\mathbf{S}$ \\
\hline A12004S-27 & IDO694/N9016/3/JFSN*4/IDO584 (70-5)//Lassik & $\mathrm{S}$ & $\mathrm{S}$ & $\mathrm{S}$ & $\mathrm{S}$ \\
\hline A12004S-28 & IDO694/N9016/3/JFSN*4/IDO584 (70-5)//Lassik & $\mathrm{S}$ & $\mathrm{S}$ & $\mathrm{S}$ & $\mathrm{S}$ \\
\hline A12004S-29 & IDO694/N9016/3/JFSN*4/IDO584 (70-5)//Lassik & $\mathrm{S}$ & $\mathrm{S}$ & $\mathrm{S}$ & $\mathrm{S}$ \\
\hline A12004S-30 & IDO694/N9016/3/JFSN*4/IDO584 (70-5)//Lassik & $\mathrm{S}$ & $\mathrm{S}$ & $\mathrm{S}$ & $\mathrm{S}$ \\
\hline A12041S-1 & IDO851/N9016//IDO851 & $\mathrm{S}$ & $\mathrm{S}$ & $\mathrm{S}$ & $\mathrm{S}$ \\
\hline A12041S-3 & IDO851/N9016//IDO851 & $\mathrm{S}$ & $\mathrm{S}$ & $\mathrm{S}$ & $\mathrm{S}$ \\
\hline A12041S-4 & IDO851/N9016//IDO851 & $\mathrm{S}$ & $\mathrm{S}$ & $\mathrm{S}$ & $\mathrm{S}$ \\
\hline A12041S-5 & IDO851/N9016//IDO851 & $\mathrm{S}$ & $\mathrm{S}$ & $\mathrm{S}$ & $\mathrm{S}$ \\
\hline A12079S-1 & IDO686/N9016//IDO686 & $\mathrm{S}$ & $\mathrm{S}$ & S & $\mathrm{S}$ \\
\hline A12089S-3 & IDO687/N9016//IDO687 & $\mathrm{S}$ & $\mathrm{S}$ & $\mathrm{S}$ & $\mathrm{S}$ \\
\hline A12089S-6 & IDO687/N9016//IDO687 & $\mathrm{R}$ & $\mathrm{H}$ & $\mathrm{R}$ & $\mathrm{R}$ \\
\hline A12089S-7 & IDO687/N9016//IDO687 & $\mathrm{S}$ & $\mathrm{S}$ & $\mathrm{S}$ & $\mathrm{S}$ \\
\hline A12089S-8 & IDO687/N9016//IDO687 & $\mathrm{S}$ & $\mathrm{S}$ & $\mathrm{S}$ & $\mathrm{S}$ \\
\hline A12089S-9 & IDO687/N9016//IDO687 & $\mathrm{S}$ & $\mathrm{S}$ & $\mathrm{S}$ & $\mathrm{S}$ \\
\hline A12089S-10 & IDO687/N9016//IDO687 & $\mathrm{S}$ & $\mathrm{S}$ & $\mathrm{S}$ & $\mathrm{S}$ \\
\hline A12089S-11 & IDO687/N9016//IDO687 & $\mathrm{S}$ & $\mathrm{S}$ & $\mathrm{S}$ & $\mathrm{S}$ \\
\hline A12089S-12 & IDO687/N9016//IDO687 & $\mathrm{R}$ & $\mathrm{R}$ & $\mathrm{R}$ & $\mathrm{R}$ \\
\hline A12089S-13 & IDO687/N9016//IDO687 & $\mathrm{S}$ & $\mathrm{S}$ & $\mathrm{S}$ & $\mathrm{S}$ \\
\hline A12089S-14 & IDO687/N9016//IDO687 & $\mathrm{S}$ & $\mathrm{S}$ & $\mathrm{S}$ & $\mathrm{S}$ \\
\hline A12089S-16 & IDO687/N9016//IDO687 & $\mathrm{S}$ & $\mathrm{S}$ & $\mathrm{S}$ & $\mathrm{S}$ \\
\hline A12089S-18 & IDO687/N9016//IDO687 & $\mathrm{S}$ & $\mathrm{S}$ & $\mathrm{S}$ & $\mathrm{S}$ \\
\hline A12089S-19 & IDO687/N9016//IDO687 & $\mathrm{S}$ & $\mathrm{S}$ & $\mathrm{S}$ & $\mathrm{S}$ \\
\hline A12089S-20 & IDO687/N9016//IDO687 & $\mathrm{S}$ & $\mathrm{S}$ & $\mathrm{S}$ & $\mathrm{S}$ \\
\hline A12089S-21 & IDO687/N9016//IDO687 & $\mathrm{S}$ & $\mathrm{S}$ & $\mathrm{S}$ & $\mathrm{S}$ \\
\hline A12039S-2 & IDO851/Futai 8944//IDO854 & $\mathrm{R}$ & $\mathrm{H}$ & $\mathrm{R}$ & $\mathrm{R}$ \\
\hline A12039S-3 & IDO851/Futai 8944//IDO854 & $\mathrm{S}$ & $\mathrm{S}$ & $\mathrm{S}$ & $\mathrm{S}$ \\
\hline
\end{tabular}

*Disagreements between PFT_KASP and UMN10 are highlighted in red font.

**R- presence of resistant allele; S- presence of susceptible allele in case of UMN10 and absence of allele for PFT_KASP, PFT_GSP and SGNH_GSP; H-presence of both resistant and susceptible alleles; S3- presence of non-functional PFT allele (S3 haplotype) 


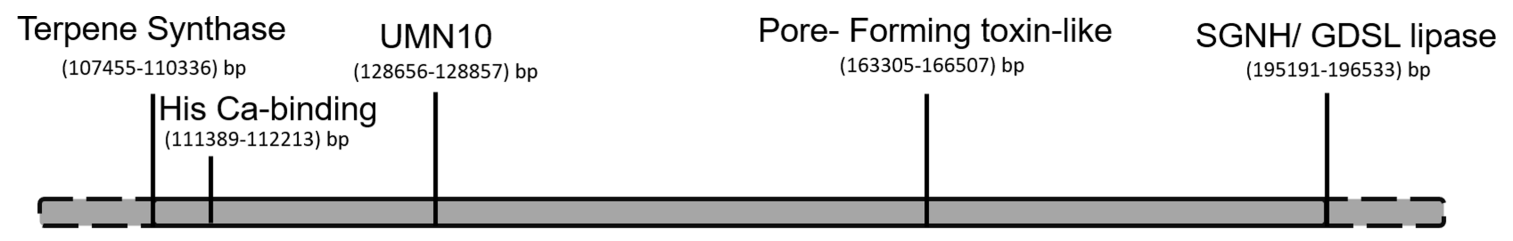

$10 \mathrm{~kb}$

Fig. 3. Order and location of genes and markers on Fhbl genomic assembly (Rawat et al., 2016) used to resolve the haplotypes of the eight breeding lines/cultivars with disagreement between UMN10 and PFT.

To validate the specificity of PFT_KASP, it was used in conjunction with SGNH_GSP, PFT_GSP and UMN10 marker to genotype a set of 75 spring wheat breeding lines from Idaho's wheat breeding program (Table 2). Thirteen lines were found to be resistant with PFT_KASP, SGNH GSP and PFT_GSP, whereas three additional lines gave 'R' genotype with UMN10. Out of 13 lines, seven lines were scored as heterozygous $(\mathrm{H})$ containing both $\mathrm{R}$ and $\mathrm{S}$ alleles for UMN10. The lines that showed the resistant haplotype with PFT_KASP had Sumai 3- derived or related Fhb1 gene in their pedigree. Similarly, in the panel of 223 cultivar and breeding lines from Minnesota, 24 were found to be resistant using PFT_KASP, SGNH_GSP and PFT_ GSP markers, whereas, five additional lines were scored as ' $\mathrm{R}$ ' using UMN10 marker (Supplementary Table 2). Out of 24 resistant lines, 4 lines scored as $\mathrm{H}$ containing both $\mathrm{R}$ and $\mathrm{S}$ alleles for UMN10. The genotyping data for all 298 lines was in complete agreement with each other for PFT_KASP, SGNH_GSP and PFT_GSP markers, whereas 8 disagreements were observed between them and the UMN10 marker.

The disagreement in genotypes of the eight lines for PFT_KASP and UMN10 among the total 298 lines screened could be due to any genetic recombination that may be present between PFT and UMN10 or a possibility of a different haplotype in these lines as compared to other susceptible haplotypes. It should be noted that rate of recombination is known to be very low for this region (Schweiger et al., 2016). To discern the origin of the disagreement in these lines, we sequenced two genes located upstream of UMN10 in the Fhb1 region: Histidine rich calcium-binding protein (His) and Terpene Synthase (TS). Fig. 3 shows the location and order of all the markers used for resolving the disagreements. The sequences of His and $T S$ matched to the ' $\mathrm{R}$ ' haplotype in all the eight entries with disagreements, whereas PFT and SGNH genotyping showed them to be susceptible haplotypes (Table 3), this
Table 3. Haplotypes of genes spanning Fhb1 region in the eight lines showing disagreements between PFT_KASP and UMN10 genotyping

\begin{tabular}{|c|c|c|c|c|c|}
\hline \multirow{2}{*}{ Entry } & \multicolumn{5}{|c|}{ Gene/marker ${ }^{\mathrm{a}}$ Haplotypes } \\
\hline & $T S^{b}$ & $H i s^{\mathrm{b}}$ & UMN10 ${ }^{c}$ & $P F T^{\mathrm{c}}$ & $S G N H^{\mathrm{c}}$ \\
\hline IDO1603S & $\mathrm{R}$ & $\mathrm{R}$ & $\mathrm{R}$ & S3 & $\mathrm{S}$ \\
\hline A12004S-19 & $\mathrm{R}$ & $\mathrm{R}$ & $\mathrm{R}$ & S3 & $\mathrm{S}$ \\
\hline A12004S-24 & $\mathrm{R}$ & $\mathrm{R}$ & $\mathrm{R}$ & $\mathrm{S} 3$ & $\mathrm{~S}$ \\
\hline H0900081 & $\mathrm{R}$ & $\mathrm{R}$ & $\mathrm{R}$ & S3 & $\mathrm{S}$ \\
\hline Lassik & $\mathrm{R}$ & $\mathrm{R}$ & $\mathrm{R}$ & $\mathrm{S} 3$ & $\mathrm{~S}$ \\
\hline UC1603 & $\mathrm{R}$ & $\mathrm{R}$ & $\mathrm{R}$ & $\mathrm{S} 3$ & $\mathrm{~S}$ \\
\hline UC1618 & $\mathrm{R}$ & $\mathrm{R}$ & $\mathrm{R}$ & $\mathrm{S} 3$ & $\mathrm{~S}$ \\
\hline 9263 & $\mathrm{R}$ & $\mathrm{R}$ & $\mathrm{R}$ & $\mathrm{S} 3$ & $\mathrm{~S}$ \\
\hline
\end{tabular}

${ }^{\mathrm{a}}$ Genes/markers in Sumai 3 Fhb1 region sequence (KX907434.1) where TS: Terpene Synthase, His: Histidine rich calcium-binding protein, PFT: Pore-forming toxin-like gene, and SGNH: SGNH Plant lipase

${ }^{\mathrm{b}}$ Haplotypes identified based on sequencing

${ }^{\mathrm{c}}$ Haplotypes identified based on genotyping with markers

was similar to a previously characterized susceptible ' $\mathrm{S} 3$ ' haplotype reported in Rawat et al. (2016). The ' $R$ ' score for these eight lines identified with UMN10 was not accurate and further validated the sensitivity of PFT_KASP assay and lack of polymorphism in UMN10 between R and S3 haplotypes. Previously, UMN10 has been used for conducting MAS for Fhbl with an assumption of tight marker and trait linkage (Zhang et al., 2016). However, the UMN10 based KASP marker developed in a previous study detected some false positives (Rasheed et al., 2016). Thus, our results underscore the limitation of linked markers over perfect markers.

PFT_KASP is a perfect diagnostic marker for Fhbl and will be a valuable resource for wheat breeders to develop FHB resistant cultivars. It will enhance the efficiency of introgression and pyramiding of FHB resistance genes in wheat varieties. 


\section{Acknowledgements}

This work was supported by the USDA National Institute of Food and Agriculture, Hatch project 1016879 and Maryland Agricultural Experiment Station via MAES Grant No. 2956952.

\section{References}

Anderson, J. A., Stack, R. W., Liu, S., Waldron, B. L., Fjeld, A. D., Coyne, C., Moreno-Sevilla, B., Fetch, J. M., Song, Q. J., Cregan, P. B. and Frohberg, R. C. 2001. DNA markers for Fusarium head blight resistance QTLs in two wheat populations. Theor. Appl. Genet. 102:1164-1168.

Anderson, J. A., Chao. S. and Liu. S. 2007. Molecular breeding using a major QTL for Fusarium head blight resistance in wheat. Crop Sci. 47:S112-S119.

Babiker, E. M., Gordon, T. C., Chao, S., Newcomb, M., Rouse, M. N., Jin, Y., Wanyera, R., Acevedo, M., Brown-Guedira, G., Williamson, S. and Bonman, J. M. 2015. Mapping resistance to the Ug99 race group of the stem rust pathogen in a spring wheat landrace. Theor. Appl. Genet. 128:605-612.

Bai, G. and Shaner, G. 1994. Scab of wheat: prospects for control. Plant Dis. 78:760-766.

Bennett, J. W. and Klich, M. 2003. Mycotoxins. Clin. Microbiol. Rev. 16:497-516.

Bernardo, A. N., Ma, H., Zhang, D. and Bai, G. 2012. Single nucleotide polymorphism in wheat chromosome region harboring Fhbl for Fusarium head blight resistance. Mol. Breed. 29:477-488.

Buerstmayr, H., Ban, T. and Anderson, J. A. 2009. QTL mapping and marker-assisted selection for Fusarium head blight resistance in wheat: a review. Plant Breed. 128:1-26.

Cabral, A. L., Jordan, M. C., McCartney, C. A., You, F. M., Humphreys, D. G., MacLachlan, R. Pozniak, C. J. 2014. Identification of candidate genes, regions and markers for preharvest sprouting resistance in wheat (Triticum aestivum L.). BMC Plant Biol. 14:340.

Goswami, R. S. and Kistler, H. C. 2004. Heading for disaster: Fusarium graminearum on cereal crops. Mol. Plant Pathol. 5:515-525.

Gupta, P. K., Roy, J. K. and Prasad, M. 2001. Single nucleotide polymorphisms: a new paradigm for molecular marker technology and DNA polymorphism detection with emphasis on their use in plants. Curr. Sci. 80:524-535.

Liu, S., Pumphrey, M., Gill, B., Trick, H. N., Zhang, J. X., Dolezel, J., Chalhoub, B. and Anderson, J. A. 2008. Toward positional cloning of Fhb1, a major QTL for Fusarium head blight resistance in wheat. Cereal Res. Commun. 36:195-201.

McMullen, M., Jones, R. and Gallenberg, D. 1997. Scab of wheat and barley: A re-emerging disease of devastating impact. Plant Dis. 81:1340-1348.

McMullen, M., Bergstorm, G., De Wolf, E., Dill-Mackey, R.,
Hershamn, D., Shaner, G. and Van Sanford, D. 2012. A unified effort to fight an enemy of wheat and barley: Fusarium Head blight. Plant Dis. 96:1712-1728.

Miedaner, T., Wilde, F., Steiner, B., Buerstmayr, H., Korzun, V. and Ebmeyer, E. 2006. Stacking quantitative trait loci (QTL) for Fusarium head blight resistance from non-adapted sources in an European elite spring wheat background and assessing their effects on deoxynivalenol (DON) content and disease severity. Theor. Appl. Genet. 112:562-569.

Neelam, K., Brown-Guedira, G. and Huang, L. 2013. Development and validation of a breeder-friendly KASPar marker for wheat leaf rust resistance locus Lr21. Mol. Breed. 31:233237.

Nganje, W. E., Bangsund, D. A., Leistritz, F. L. Wilson, W. W. and Tiapo, N. M. 2004. Regional economic impacts of Fusarium head blight in wheat and barley. Rev. Agric. Econ. 26:332-347.

Rasheed, A., Wen, W., Gao, F., Zhai, S., Jin, H., Liu, J., Guo, Q., Zhang, Y., Dreisigacker, S., Xia, X. and He, Z. 2016. Development and validation of KASP assays for genes underpinning key economic traits in bread wheat. Theor. Appl. Genet. 129:1843-1860.

Rawat, N., Pumphrey, M. O., Liu, S., Zhang, X., Tiwari, V. K., Ando, K., Trick, H. N., Bockus, W. W., Akhunov, E., Anderson, J. A. and Gill, B. S. 2016. Wheat Fhb1 encodes a chimeric lectin with agglutinin domains and a pore-forming toxinlike domain conferring resistance to Fusarium head blight. Nat. Genet. 48:1576-1580.

Schroeder, H. W. and Christensen, J. J. 1963. Factors affecting resistance of wheat to scab caused by Gibberella zeae. Phytopathology 53:831-838.

Schweiger, W., Steiner, B., Vautrin, S., Nussbaumer, T., Siegwart, G., Zamini, M., Jungreithmeier, F., Gratl, V., Lemmens, M., Mayer, K. F., Berges, H., Adam, G. and Buerstmayr, H. 2016. Suppressed recombination and unique candidate genes in the divergent haplotype encoding Fhb1, a major Fusarium head blight resistance locus in wheat. Theor. Appl. Genet. 129:1607-1623.

Semagn, K., Babu, R., Hearne, S. and Olsen, M. 2014. Single nucleotide polymorphism genotyping using Kompetitive Allele Specific PCR (KASP): overview of the technology and its application in crop improvement. Mol. Breed. 33:1-14.

Shin, S., Son, J. H., Park, J. C., Kim, K. H., Yoon, Y. M., Cheong, Y. K., Kim, K. H., Hyun, J. N., Park, C. S., Dill-Macky, R. and Kang, C. S. 2018. Comparative pathogenicity of Fusarium graminearum isolates from wheat kernels in Korea. Plant Pathol. J. 34:347-355.

Singh, B. D. and Singh, A. K. 2015. Sequence-based markers. In: Marker-assisted plant breeding: principles and practices, eds. by B. D. Singh and A. K. Singh, pp. 77-122. Springer, New Delhi, India.

Steiner, B., Buerstmayr, M., Michel, S., Schweiger, W., Lemmens, M. and Buerstmayr, H. 2017. Breeding strategies and advances in line selection for Fusarium head blight resistance 
in wheat. Trop. Plant Pathol. 42:165-174.

Su, Z., Jin, S., Zhang, D. and Bai, G. 2018. Development and validation of diagnostic markers for Fhb1 region, a major QTL for Fusarium head blight resistance in wheat. Theor. Appl. Genet. 131:2371-2380.

Tan, C.-T., Assanga, S., Zhang, G., Rudd, J. C., Haley, S. D., Xue, Q., Ibrahim, A., Bai, G., Zhang, X., Byrne, P., Fuentealba, M. P. and Liu, S. 2017. Development and Validation of KASP Markers for Wheat Streak Mosaic Virus Resistance Gene Wsm2. Crop Sci. 57:340-349.

Wilde, F., Korzun, V., Ebmeyer, E., Geiger, H. H. and Miedaner, T. 2007. Comparison of phenotypic and marker-based selection for Fusarium head blight resistance and DON content in spring wheat. Mol. Breed. 19:357-370.

Windels, C. E. 2000. Economic and social impacts of Fusarium head blight: Changing farms and rural communities in the Northern Great Plains. Phytopathology 90:17-21.
Xiao, J., Jia, X., Wang, H., Zhao, R., Fang, Y., Gao, R., Wu, Z., Cao, A., Wang, J., Xue, Z., Zhao, W., Kang, J., Chen, Q., Chen, P. and Wang, X. 2011. A fast-neutron induced chromosome fragment deletion of 3BS in wheat landrace Wangshuibai increased its susceptibility to Fusarium head blight. Chromosome Res. 19:225-234.

Xie, G. Q., Zhang, M. C., Chakraborty, S. and Liu, C. J. 2007. The effect of 3BS locus of Sumai 3 on Fusarium head blight resistance in Australian wheats. Aust. J. Exp. Agric. 47:603607.

Zhang, X., Rouse, M. N., Nava, I. C., Jin, Y. and Anderson, J. A. 2016. Development and verification of wheat germplasm containing both $\mathrm{Sr} 2$ and Fhb1. Mol. Breed. 36:85.

Zhou, W. C., Kolb, F. L., Bai, G. H., Domier, L. L., Boze, L. K. and Smith, N. J. 2003. Validation of a major QTL for scab resistance with SSR markers and use of marker-assisted selection in wheat. Plant Breed. 122:40-46. 